\title{
PRESETTLEMENT VEGETATION OF SOUTHERN BEAVERHEAD COUNTY, MONTANA
}

\author{
Peter Lesica \& Stephen V. Cooper \\ Montana Natural Heritage Program \\ P.O. Box 201800 \\ 1515 East Sixth Avenue \\ Helena, Montana 59620-1800 \\ (c) 1997 Montana Natural Heritage Program \\ Prepared for: \\ USDI Bureau of Land Management \\ State Office \\ P.O. Box 36800 \\ Billings, MT 59107-6800 \\ (Assistance Agreement No. 1422-E950-A1-0006; Task Order \# 32) \\ and \\ USDA Forest Service \\ Beaverhead-Deerlodge National Forest \\ 420 Barrett Street \\ Dillon, MT 59725 \\ (Challenge Cost-Share Agreement No. 11-01-02-95-36)
}

This document should be cited as follows:

Lesica, P. and S. V. Cooper. 1997. Presettlement vegetation of southern Beaverhead County, Montana. Unpublished report to the State Office, Bureau of Land Management and Beaverhead-Deerlodge National Forest. Montana Natural Heritage Program, Helena, MT. 35 pp. 


\section{CONTENTS}

INTRODUCTION

METHODS

RESULTS.

Hypothesis 1. Bison were common in southern Beaverhead County

Hypothesis 2. Livestock grazing was common in the later part of the $19^{\text {th }}$

Century

Hypothesis 3. Palatable bunch grasses had a higher density, and unpalatable

forbs had a lower density....

Hypothesis 4. Coniferous forests were less extensive, and densities of coniferous trees were lower.

Hypothesis 5. Aspen (Populus tremuloides) forests were more extensive

Hypothesis 6. Sagebrush (Artemisia spp.) steppe was less extensive, and density of sagebrush was lower.

Hypothesis 7. Basin big sagebrush (A. tridentata ssp. tridentata) was more common along many streams.

Hypothesis 8. Basin wildrye (Elymus cinereus) was more common along many streams.....

Hypothesis 9. Willows (Salix spp.) were more common along many streams ... 14 Hypothesis 10. Mountain mahogany (Cercocarpus ledifolius) woodland was less extensive 15

Hypothesis 11. Cottonwood (Populus trichocarpa, $P$. angustifolia) forests were more extensive

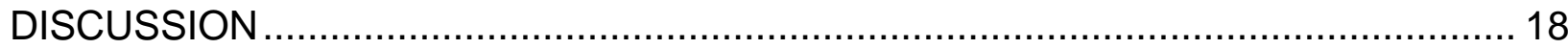

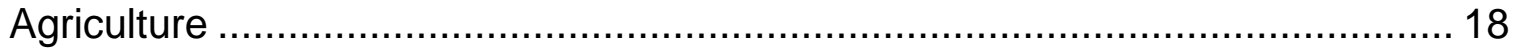

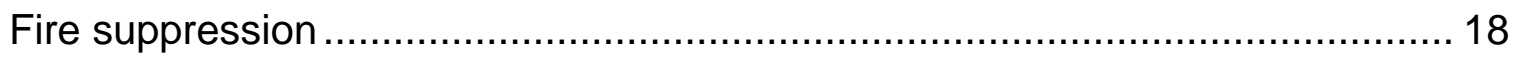

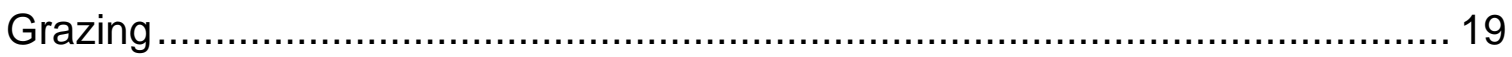




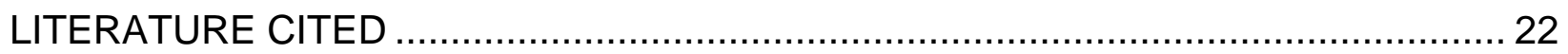

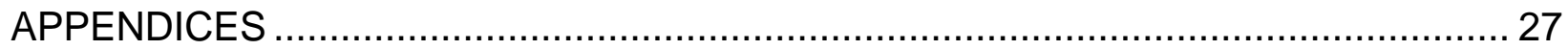

A. Observations of bison made by early trappers in Beaverhead and adjacent

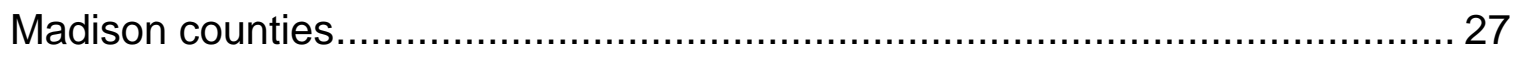

B. Comparison of vegetation dominated by Elymus cinereus or Artemisia tridentata ssp. tridentata inside and outside livestock exclosures in southern

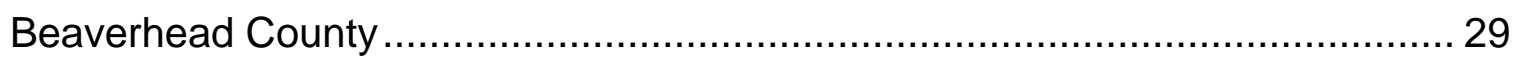

C. Number of willow plants along steam banks inside and outside of livestock exclosures on three stream reaches in southern Beaverhead County

\section{TABLES:}

1. Hypotheses on presettlement vegetation of southern Beaverhead County 4 


\section{INTRODUCTION}

Individual species have evolved with and adapted to landscapes that remain relatively stable for thousands of years. In a comparativley short time Europeans have radically changed many of these systems through fire suppression, water diversion and livestock grazing. Knowing how landscapes have changed during the past century allows managers to better understand what conditions plants and animals are adapted to and to develop hypotheses regarding changes in their abundance and distribution. Unfortunately, there is little systematically collected information on presettlement vegetation. Nonetheless, much can be learned about presettlement vegetation from accounts of early explorers and travellers and early photographs (Dorn 1986, Gilkerson 1980, Gruell 1983, Vale 1975).

Our study uses historical evidence to describe presettlement vegetation in various parts of southern Beaverhead County and adjacent areas. We then compare these descriptions to current vegetation to determine how it has changed in the interim. Finally, we infer the causes of observed changes using information from the ecological research literature.

\section{METHODS}

Our study area is Beaverhead County south of the lowest reach of the Big Hole River, just north of the town of Dillon. We have also included information from adjacent northern Beaverhead County, Madison County and Lemhi County, Idaho.

At the start of our study we proposed a set of hypotheses suggested to us by previous studies or our personal experience (Table 1). We collected information relating to these hypotheses from three sources. Primary sources of information are journals of explorers and early settlers that traveled through or lived in the area (Knowles and Knowles 1993). We collected descriptions of vegetation from these sources and revisited the described areas in August 1996 to determine how vegetation 
Table 1. Hypotheses on presettlement vegetation of southern Beaverhead County. We found no information for hypotheses 12-15.

1. Bison were common in southern Beaverhead County.

2. Livestock grazing was common in the later part of the 19th Century.

3. Palatable bunch grasses had a higher density, and unpalatable forbs had a lower density.

4. Coniferous forests were less extensive, and densities of coniferous trees were lower.

5. Aspen (Populus tremuloides) forests were more extensive.

6. Sagebrush (Artemisia spp.) steppe was less extensive, and density of sagebrush was lower.

7. Basin big sagebrush (A. tridentata ssp. tridentata) was more common along many streams.

8. Basin wildrye (Elymus cinereus) was more common along many streams.

9. Willows (Salix spp.) were more common along many streams.

10. Mountain mahogany (Cercocarpus ledifolius) woodland was less extensive.

11. Cottonwood (Populus trichocarpa, P. angustifolia) forests were more extensive.

12. Relative abundance of three-tip sagebrush (Artemisia tripartita) compared to big sagebrush has declined.

13. Toxic forbs have increased and palatable forbs have decreased

14. Tufted hairgrass (Deschampsia cespitosa) has decreased in wetlands and riparian areas.

15. Baltic rush (Juncus balticus) has increased in wetland areas. 
had changed. These are the most reliable sources of information because many of the descriptions predate livestock grazing in the study area.

Meriwether Lewis and William Clark led an exploratory expedition for the U.S. Government in 1804-06.

Warren A. Ferris was a fur trapper in Montana in 1831-34.

John Work was a British fur trader in Montana in 1831-32.

Osborne Russell was a fur trapper in Montana in 1834-43.

John Mullan led a survey party for the Stevens Railroad Survey in Montana in 1853-54.

William Raynolds led a U.S. Army expedition exploring Montana in 1859-60.

Granville Stuart was a rancher and businessman in Montana from 1857-1919.

Albert Brackett was a colonel in the U.S. Army in Montana in 1869.

Ferdinand Hayden led expeditions for the U.S. Geological Survey in Montana in 1871 and 1872.

Secondary sources are compilations of old/modern comparison photography (Gilkerson 1980, Gruell 1983). The earliest photographs examined date from the 1870 's. However, most are from near the turn of the century or later, well after livestock grazing was common in the 1870's. We did not use photographs taken after 1910 to examine the effects of grazing.

Tertiary sources are data gathered from intentional or unintentional experiments conducted in the study area; i.e., livestock exclosures or fence line grazing contrasts. 


\section{RESULTS}

Hypotheses, stated in bold print, are considered below in order in which they appear in Table 1.

\section{Bison were common in southern Beaverhead County.}

Bison were generally commented on and reported to be common by the early explorers and trappers. However, it also appears that the herds moved frequently and could not always be found. Forage for livestock was minimal in areas recently grazed by bison.

Bison were common in the broad valleys below Dillon. Ferris described the Jefferson River Valley just south of Whitehall as "alive with buffalo" (Phillips 1940, p. 113), and in the lower valley of the Ruby River his men "...killed numbers of buffalo, which were numerous in all directions." "...we followed the course of the river through a narrow defile of a mile in length and descended into an open valley which we found covered buffalo." (ibid, p. 118). In the Beaverhead River Valley east of Dillon Ferris "saw several fine herds of buffalo, and our hunters reported that the plains were covered with them near Beaver Head." (Phillips 1940, p. 171). Along the Big Hole River near Melrose Work "...encamped to allow the horses to feed where there is some grass left by the buffalo." Later he states, "no buffalo to be seen on the road, but some of the men who went to the hills saw plenty ahead." (Lewis and Phillips 1923, p. 102-105). In the Dillon area, he reported, "no buffalo to be seen at our first station, but near our first encampment there are several herds..." (ibid. p. 106).

Although Lewis and Clark frequently wrote of great herds of bison around Helena, Three Forks, Great Falls and east, they did not once mention bison along the Jefferson River or Beaverhead River (Burroughs 1961). However, later travellers reported bison to be common from Dillon to the headwaters of the Red Rock River, and buffalo jumps are documented on Price and Sweetwater creeks near the headwaters of the Ruby River (Scarborough 1974). Ferris described Horse Prairie west of Clark Canyon Reservoir as "a famous resort for them (bison)" although they did not see any when they passed through (Phillips 1940, p. 110, 256). Work reported large herds of bison and signs of bison in the Horse Prairie area (Lewis and Phillips 1923, p. 109, 121) and referred to a "bison road" at Bannack Pass (ibid. p. 136). He also mentioned that 
near Clark's Canyon "...the buffalo have eaten up what grass there was, short way farther down the river there is good grass." (ibid. p. 123). Osborne Russell spoke of the Centennial Valley, "This Valley as a Mountaineer would say was full of buffalo..." (Haines 1955, p.34).

The high valleys west of the Continental Divide in adjacent Idaho apparently also received sporadic use by bison. Traveling north through Idaho up Birch Creek and down the Lemhi Valley Ferris reported "we have not seen a vestige of buffalo since leaving the Big Lost River" (Phillips 1940, p. 99). Work first reported that the lower and mid-Lemhi Valley had no bison and the grass was good. (Lewis and Phillips 1923, p. 114-117). However, he later stated that the Lemhi Valley was a "favorite resort of buffalo" (ibid. p. 130, p. 161), and bison were common around Leadore (ibid., p. 118119).

Bison were generally observed grazing in upland habitats in the fall and winter. Only two of 22 references to bison and their habitat indicate that they may have been grazing in riparian habitat (Appendix A.).

\section{Livestock grazing was common in the later part of the 19th Century.}

Large-scale livestock grazing in Beaverhead County began in the 1860's. At this time there were few bison remaining. By the 1870's ranging cattle on a large scale had become a problem (Scarborough 1974). Bracket (1917) reported that the quality of grass varied greatly between Monida and the Ruby River in 1869. Photographs taken in 1871 south of Dillon and near Monida Pass show rangeland with much bare soil and little grass cover. Photographs taken 110 years later depict much higher canopy cover of grass (Gruell 1983; plates 50, 52). Moist grasslands near Henry's lake were dominated by snowberry (Symphoricarpos) and a large forb (possibly Helenium hoopsii) in 1872 but supported productive sagebrush-bunchgrass steppe 110 years later (Gruell 1983, plate 58), suggesting that the 1872 vegetation was a grazing disclimax.

\section{Palatable bunch grasses had a higher density, and unpalatable forbs were less common.}


Information on herbaceous vegetation is very limited, and only reports from before the advent of the livestock industry in ca. 1860 accurately portray presettlement conditions. Early reports provide no evidence that upland herbaceous vegetation was different than in modern times.

Lewis described the upland vegetation of Horse Prairie in 1905. "the uplands are covered with prickly pears and twisted or bearded grass (Stipa comata, Agropyron spicatum) and are but poor; some parts of the bottom lands are covered with grass and tolerably fertile; but much the greater proportion is covered with prickly pears, sedge, twisted grass, the pulpy leafed thorn (Sarcobatus vermiculatus) southernwood wild sage (Artemisia tridentata) and like the uplands is very inferior in point of soil." (Moulton and Dunlay 1988, p. 65). Upland vegetation of Horse Prairie is similar today; sagebrush and greasewood are common, bluebunch wheatgrass and needle-and-thread are the dominant grasses, and prickly pear is abundant.

In 1831 Ferris described the upland vegetation of the Beaverhead Valley near Beaverhead Rock. "The plains are everywhere covered with prickly pear, which constitutes one of the greatest evils that we have to encounter in this country..." (Phillips 1940, p. 116). Mullan gave a similar description twenty years later: "The valley... covered with an excellent growth of bunch grass. There, however, as throughout the valley, the cactus or prickly pear occurs in the greatest abundance" (Mullan 1885, p. 340). Much of the Beaverhead Valley north of Dillon has been converted to agriculture; however, north of Birch Creek native vegetation in the valley is dominated by bunchgrass with a high density of cactus just as Mullan described it.

\section{Coniferous forests were less extensive, and densities of coniferous trees were lower.}

Fire history studies indicate that forests were confined to rocky or mesic sites prior to European settlement, but there has been a substantial increase in conifers at the forest-grassland ecotone (Arno and Gruell 1983, 1986). Comparison photography shows that the density of conifers has increased near Bannack, Monida, Blacktail Deer Creek, the upper Ruby Valley and the Centennial Mountains since the early part of this century (Gruell 1983; plates 48, 49, 52, 54, 55, 57, 59, 63; Gilkerson 1980, p. 32). Conifers have invaded grassland and steppe vegetation near Monida, Blacktail Deer 
Creek and the Centennial Mountains (Gruell 1983; plates 52, 55, 57, 59). Photographs of Hellroaring Creek in the Centennial Valley in ca. 1895 show numerous openings with burned snags (Brower 1897) where there is now dense forest.

\section{Aspen (Populus tremuloides) forests were more extensive.}

Aspen stands still occur now in most places they were found at the time of European settlement. On average, modern stands are older, often approaching decadence, and are being replaced by conifers in many places.

Mullan reported small stands of aspen on Blacktail Deer Creek below Price Canyon: "...its left bank, finding here good grass, water and wood, the latter being quaking aspen" (Mullan 1855, p. 339), and "This stream is timbered by willow bushes, save at one or two places small clumps of quaking aspen were to be seen" (ibid., p. 339). Small groves of aspen still occur in the foothills of the Blacktail Mountains west of the creek ca. three and ten miles below Price Canyon. Osborne Russell described extensive aspen stands west of the Madison River near Cliff Lake: "On the west the bluffs were covered with thick groves of quaking aspen..." (Haines 1955, p. 30). Many of these stands have been replaced, or are now dominated, by conifers and the remaining aspen stands are decadent.

Early photographs taken near Snowline (1871), Red Rock Pass (1928), Henry's Lake (1872), the Madison Valley (1927), the Gravelly Range (1916), and the Ruby Valley (1936) depict young stands of aspen in foothills settings. Recent comparison photographs show that these stands have matured (Gruell 1983; plates 51, 56, 58, 60, $62,63)$. At Snowline and in the Madison and Ruby valleys these older stands are being replaced by Douglas fir.

\section{Sagebrush (Artemisia spp.) steppe was less extensive and within sagebrush stands shrub density was lower.}

Sagebrush was abundant in the Red Rock River Valley but was less common in the Blacktail Deer Creek and Beaverhead River valleys in the presettlement era. Many of the areas dominated by bunchgrass then remain so today. Although sagebrush steppe and grassland still form a mosaic across the landscape, it appears that sagebrush has increased in more places than it has decreased (Arno and Gruell 1986). 
John Mullan described the Beaverhead Valley north of Dillon " The valley... covered with an excellent growth of bunch grass. There, however, as throughout the valley, the cactus or prickly pear occurs in the greatest abundance. Our trail at times led through patches of sage, though not at all inconveniencing our travelling" (Mullan 1885, p. 340). Just south of Dillon an 1871 photograph shows lower slopes along the Beaverhead River with little or no sagebrush, while it is common in a comparison photograph from 1981 Gruell 1983, plate 50). Much of the Beaverhead Valley north of Dillon has been converted to agriculture; however, north of Birch Creek native vegetation in the valley is dominated by bunchgrass with a high density of cactus (Opuntia polyacantha) with only scattered sagebrush, just as Mullan described it. Sagebrush steppe now dominates the slopes along the Beaverhead River south of Dillon.

Mullan found sagebrush in much of the Red Rock River Valley in 1853: "We found the soil of this valley principally of a yellowish or grayish yellow colored clay, upon which, throughout its whole length, the wild sage grows in the greatest abundance. On the lower and upper portions of this valley we found the grass to be exceedingly rich, but near the middle nothing growing save the wild sage bushes (Mullan 1855, p. 329). He also observed sagebrush around the present town of Dell and in the Sage Creek Valley: "The portion of the valley bordering these buttes is formed of reddish clay, a soil resulting from the washings of these buttes up which nothing grows but the artemisia or wild sage" (ibid., p.329). He passed from the Red Rock Valley through Sage Creek, "The valleys between these low ridges were covered with artemisia or wild sage growing from eighteen inches to three feet high (ibid., p. 338). Vegetation along the Red Rock River Valley between Horse Prairie Creek and Lima is now a mosaic of grasslands and low- to moderate-density sagebrush steppe. Sagebrush is at low density and often confined to swales in lower Sage Creek, but becomes dense in the upper reaches.

Apparently Mullan observed vegetation dominated by grasslands in the Blacktail Deer Creek Valley below the forks: "This valley is about two miles wide, lined on each side by a range of timbered mountains, and covered with a rich and beautiful growth of bunch grasses." "This valley throughout is well grassed, and at present being perfectly free from snow, looks not unlike a large field of yellow grain" (Mullan 1855, p. 339). An 1872 photograph from the same area also depicts low sagebrush density (Gruell 1983, 
plate 55). Sagebrush density is still low along Blacktail Deer Creek below Price Canyon in 1996.

Much of the country south of the Pioneer Range to Horse Prairie was dominated by sagebrush prior to significant European settlement. John Mullan described the area southeast of Big Hole Pass. "After crossing the divide above referred to, our trail led us through a large prairie plain covered with the artemisia or wild sage growing to a height of two to three feet" (Mullan 1855, p. 327). The Lewis and Clark Expedition encountered sagebrush in the country between Bannack and Horse Prairie: "...great quantities of the species of hysoop (Artemisia tridentata) and shrubs common to the Missouri plains are scattered in those hills and valleys." (Moulton 1993, p. 172). Fifty years later Mullan had a similar experience in the same area: "...a series of low, sandy ridges, covered with the artemisia growing from three to four feet high." (Mullan 1855, p. 328). Sagebrush was apparently also common along Grasshopper Creek near Bannack as Granville Stuart reported that he "...several times saw miners pulling up small sagebrush that grew along creek" (Phillips 1957, I p. 232). Indeed, a photograph taken in 1880 shows sagebrush steppe on the hills above the town (Gruell 1983, plate 49). Dense sagebrush steppe dominates the modern-day landscape from Big Hole Pass to Horse Prairie.

The hills between Monida Pass and Lima were without appreciable sagebrush at the time of settlement. Granville Stuart remarked on the contrast between the Idaho and Montana sides of Monida Pass in 1857. "As soon as we had crossed the Divide a wonderful change appeared in the country. Instead of the gray sagebrush covered plains of the Snake River we saw smooth rounded hills and sloping bench land covered in yellow bunch grass that waved in the wind like a field of grain" (Phillips 1957, I p. 124). Fourteen years later the Hayden expedition had the same experience: "On the west side of the road, for ten or fifteen miles, the rounded, grass-covered hills prevailed..." "On the east side... whenever any of the branches of Dry Creek cut through the grass-covered hills..." (Hayden 1872). Stibal (1990), in her account of the Centennial Valley, stated that "old timers" told of grasses so lush you could have mowed hay on top of Monida Hill.

Sagebrush steppe, predominantly comprised of the mountain big sagebrush/Idaho fescue plant association, is now the predominant vegetation from 
Monida to Snowline, ten miles below the pass; given the current vegetation composition of these stands one can only assume that the bunchgrass so hyperbolically described in the early accounts was Idaho fescue (Festuca idahoensis). From Snowline to Lima sagebrush steppe dominates the foothills of the Tendoy Range, while grasslands prevail north of the road.

Reports from around Henry's Lake indicate that many areas may have been free of sagebrush around 1870. The Hayden expedition reported little sagebrush at Raynolds Pass: "The low pass is like a lawn- smooth and covered with grass..." (Hayden 1869, p. 89), and a later expedition described Red Rock Pass between Henry's Lake and the Centennial Valley: "...Red Rock Pass affords a broad, flat, grassy opening to Red Rock Lake..." (Hayden 1873). An 1872 photograph shows flats around Henry's Lake dominated by snowberry and forbs, while sagebrush dominates the area 110 years later (Gruell 9183, plate 58). A photograph depicts Antelope Basin west of Raynolds Pass as a grassland in ca. 1910; seventy years later the same area is sagebrush steppe (Gilkerson 1980, p. 80). Further north, near the present town of Ennis, Raynolds reported on the apparent lack of sagebrush in 1860: "All the terraces of which the valley is constituted are now covered with a luxurious growth of bunch grass, affording at this season pasturage of the finest quality and great extent" (Raynolds 1868, p. 100). Sagebrush is now common in the Red Rock Pass area and on the north side of Henry's Lake. Sagebrush steppe also dominates on both sides of Raynolds Pass except about one mile south of the pass where a recent fire has converted steppe to grassland.

\section{Basin big sagebrush (Artemisia tridentata ssp. tridentata) was more common along streams and rivers.}

Basin big sagebrush occurred along at least some drainages when the John Mullan came through in 1853. It was abundant enough in some places to provide firewood for a survey party. Basin big sagebrush is presently found primarily as narrow stringers along side drainages. Much of the broad stream terrace habitat has been converted to hay fields.

Mullan described basin big sagebrush along Grasshopper Creek near Bannack. "When passing through here before, a trail led us through a canyon of the mountains 
where we found the artemisias growing to a height of eight feet with a trunk about eight inches in diameter. This formed part of our fuel at our night's camp, together with a few dried willos" (Mullan 1855, p.327). Later in this trip he described the Red Rock Valley from Snowline to Sage Creek. "The greater portion of our road today lay through sage plains, where we found the sage in some places six and eight feet high and from eight to twelve inches in diameter " (ibid, p. 338). In today's vegetation mosaic narrow stringers of basin big sagebrush occur in a few swales near Bannack. Along the Red Rock River from Dell to Monida we observed stringers of basin big sagebrush in only two locations near Lima. Some large stands of basin big sagebrush as well as stringers at the edges of hay fields and along fences occur in lower Sage Creek near Dell.

Studies of fence line contrasts and grazing exclosures suggest that many remaining stands of basin big sagebrush have a decreased abundance of native grasses such as Agropyron smithii and Elymus cinereus (Appendix B).

\section{Basin wildrye (Elymus cinereus) was more common along many streams.}

Explorers, trappers and early settlers recorded little information on herbaceous plants. However, the scant evidence available suggests that basin wildrye was common along rivers and streams in southern Beaverhead County. Only scattered plants or sparse colonies along major water courses exist today. Scattered plants also occur over large bottomland areas in the Centennial Valley (Cooper et al. 1995). Significant stands are now confined primarily to headwaters where stream terraces have not been severely grazed or converted to hay meadows.

The Lewis and Clark Expedition observed basin wildrye along the Beaverhead River above Twin Bridges, "I observe a considerable quantity of the buffalo clover in the bottoms the sunflower, flax, green swoard, thistle, and several species of rye grass some of which rise to the hight of 3 or 4 feet." (Moulton and Dunlay 1988, p. 58). Closer to Dillon Lewis observed "fertile and covered with taller grass than usual" (ibid., p. 62). Granville Stuart implied that basin wildrye was common in the valleys of southern Beaverhead County, especially Blacktail Deer Creek: "When we came to Montana in 1858 the Grants and Jacobs had herds of several hundred cattle and horses. These cattle fattened on the native grasses without shelter other than that afforded by the 
willows and alders and tall ryegrass along the streams" (Phillips 1957, II p. 97). Basin wildrye is now confined to scattered plants on the edges of hay meadows in the Beaverhead River Valley below Dillon. Scattered plants occur between willows and hay meadows along the Red Rock River and Grasshopper, Blacktail Deer, and Sage creeks. Larger patches of basin wildrye occur on concave lower slopes near the head of Blacktail Deer Creek.

Basin wildrye is not apparent in a photograph taken near Snowline in 1871, but plants can be seen along the railroad right-of-way in a comparison photograph taken in 1981 (Gruell 1983, plate 51). Basin wildrye has decreased in abundance along a reach of Price Creek since 1872 ibid., plate 55).

Studies of fence line contrasts and livestock exclosures suggest that basin wildrye has potential to be abundant in many moist sites where it is currently uncommon or absent. Reduction in grazing pressure generally results in increased abundance of basin wildrye in these areas (Appendix B).

\section{Willows (Salix spp.) were more common along many streams.}

Willow-dominated riparian areas were common along rivers and large creeks as well as smaller order streams at the time of European settlement. Willows are still abundant along most larger streams, but there is evidence that they have declined along some smaller streams. Much of this loss may be due to irrigation diversions. Livestock grazing may also have played a role.

The Horse Prairie area was much used by early explorers and trappers. Meriwether Lewis provided a scant description of the riparian vegetation: "here we killed a deer and encamped on the stard. side and made our fire of dry willow brush, the only fuel which the country produces." (Moulton and Dunlay 1988, p. 65). Twenty-five years later Ferris provided a description of the same area: "The borders of creeks and rivulets in this valley are scantily adorned with clusters of small willows." (Phillips 1940, p. 105). Mullan described the willows along Horse Prairie Creek and the Red Rock River as much taller twenty years later: "Both branches of the Jefferson Fork are lined with willow bushes growing from five to six feet high." (Mullan 1855, p. 329). He also briefly described a camp site along Grasshopper Creek, twenty miles north: "Here is formed by the willows along the stream a natural corral..." (ibid., p. 327). In 1996, Horse Prairie 
Creek and Grasshopper Creek riparian areas support dense stands of willows 4-10 ft high.

Willows were common in riparian areas in other parts of the study area as well. Mullan described the head of Sage Creek, east of Red Rock: "Numerous mountain rivulets were crossed running through these valleys which were lined on each side by willow bushes, growing in some places to twelve feet high" (Mullan 1855, p. 338). Numerous stands of tall willows still occur among hay fields in this area. On the other hand, Raynolds described riparian areas in the Madison Valley near Cameron: "The banks of the numerous small streams emptying into the river are skirted with a narrow fugure of willows, alders and aspens..." (Raynolds 1868, p. 100). Tributaries of the Madison River in this area are now dry most of the year from irrigation diversions. Riparian areas support degenerated and broken stringers of willow and cottonwood.

Photographs taken along Price Creek, northeast of Dell (1872), around Snowline (1871), and in Idaho just south of Monida (1871) depict willows in low stream order riparian areas (Gruell 1983; plates 51, 53, 55). Modern comparison photographs show significant declines in willow cover in all three sites (ibid.). At Snowline and south of Monida, willows have been replaced by hay meadows.

Studies of grazing exclosures indicates that the abundance of willows, especially Salix bebbiana, declines with grazing pressure (Appendix C).

\section{Mountain mahogany (Cercocarpus ledifolius) woodland was less extensive.}

Early photographs taken at Bannack (1880), along the Ruby River near Sheridan (1940), the Madison River near Norris (1871) and the Big Hole River near Melrose (1910) depict stands of mountain mahogany on rocky slopes (Gruell 1983; plates 49, 64, 70; Gilkerson 1980, p. 42). Comparison photographs taken in ca. 1980 show mountain mahogany increased in density and extent at all of these sites. Along the Madison River older mahogany is being overtopped by Douglas fir (Gruell 1983, plate 70).

\section{Cottonwood (Populus trichocarpa, P. angustifolia) forests were more extensive.}


The abundance of cottonwood forests along rivers in southern Beaverhead County appears to have increased in the early half of the Nineteenth Century. Cottonwood stands are now common, but many mature cottonwood stands are in a state of decline.

Extensive riparian areas occur where the three forks of the Jefferson (Big Hole, Beaverhead, Ruby rivers) join near Twin Bridges. In 1805 Lewis described the riparian vegetation along the Beaverhead River just above Twin Bridges: "there is but very little timber on this fork, principally the under brush frequently mentioned" (Moulton and Dunlay 1988, p. 58). However, in 1831 Ferris described the three rivers differently: "All these streams are bordered by fine grass bottoms and groves of trees and willows" (Phillips 1940, p. 116). Cottonwood forests are now common along the Beaverhead River above Twin Bridges.

William Clark described the expedition's three camp sites along the Beaverhead River between Beaverhead Rock and Dillon in 1805 as follows: "there are but few trees in this bottom and those small narrow leafed cottonwood. the principal growth is willow with the narrow leaf and currant bushes" (Moulton and Dunlay 1988, p. 71); "...camped on a smooth plain to the left near a few cottonwood trees (ibid., p. 75); and "...camped in a smooth, level prairie near a few cottonwood trees, but were obliged to use willow brush for fuel" (ibid., p. 84). Mullan gave a different impression when he described the banks of the Beaverhead River near the present town of Dillon in 1853: "...its bank as far as could be seen, being lined with cottonwood growing to the height of sixty feet" Mullan 1855, p. 340). Mullan also described the mouth of Blacktail Deer Creek near the third camp used by Clark and his men: "The Hooked Man Creek near its mouth is lined with cottonwood. The willow however is the principal wood on its banks" (Mullan 1855, p. 339). Cottonwood stands are now common but declining along the Beaverhead River between Beaverhead Rock and Dillon.

Clark apparently found few cottonwoods along the Beaverhead River upstream from Dillon as well. He described their camp at Gallagher Gulch: "...we reached in the evening a small bottom, covered with clover and a few cottonwood trees" (Moulton and Dunlay 1988, p. 98). Just below the confluence of the Red Rock River and Horse Prairie Creek he climbed a promontory and reported: " from the top of this eminence we 
could discover only three trees through the whole country...the low grounds were supplied with willow currant-bushes, and service-berries" (ibid., p. 108).

In 1831 Work reported on his camp at the confluence of the Red Rock River and Horse Prairie Creek: "We have no wood here but willows..." (Lewis and Phillips 1923, p. 109). Twenty years later Mullan camped in the same spot and "...found a few cottonwood trees which afforded us an abundance of fuel... " Mullan 1855, p. 328). The following day he proceeded up the Red Rock River and described the riparian areas thus: "About fifteen miles above from our camp of last night we found the river for a distance of several miles lined with cottonwood growing to a height of seventy feet. The remaining portion of the river and its several small tributaries are unwooded save by willow bushes" (ibid., p. 329). Work camped in "a clump of poplar" near the present town of Red Rock in 1831 (Lewis and Phillips 1923, p. 123). Scattered groves of cottonwood now occur along the Beaverhead River upstream from Dillon, and numerous groves, some of them extensive, occur all along the Red Rock River from the confluence with Horse Prairie Creek south to Lima. Most of these stands are old and/or decadent.

Apparently the Lewis and Clark Expedition found few cottonwoods in Horse Prairie: "... and made our fire of dry willow brush, the only fuel which the country produces" (Moulton and Dunlay 1988, p. 65). Mullan gave the same impression 50 years later: "It, like the southwestern branch, is perfectly destitute of timber save a few cottonwood trees, growing in clumps of four or five and at least twenty miles apart" (Mullan 1855, p. 328). Small cottonwood groves now occur at the east end of Horse Prairie.

Mullan found few cottonwoods along Grasshopper Creek northwest of Bannack: "This section is exceedingly barren of timber- none whatever to be seen, save the pine of the mountain top, and at intervals of from fifteen to twenty miles an old cottonwood would spring into view..." "... no fuel but wild sage bushes and a few dried willows" (Mullan 1885, p. 327). Cottonwoods are still absent from this reach of Grasshopper Creek.

Photographs taken in 1910 depict scattered and mostly young cottonwoods along the Big Hole River near Dewey and Melrose (Gilkerson 1980, p. 52, 54, 58). 
Comparison photographs taken 70 years later show taller and more extensive cottonwood forests in both areas.

\section{DISCUSSION}

The vegetation of southern Beaverhead County is much the same today as it was during the 19th Century. Forests dominated by Douglas fir occurred on cool slopes. Aspen groves were common in moist, cool or depressional sites in some foothills areas. Juniper and mountain mahogany were associated with rocky outcrops. The dominant upland vegetation was a mosaic of fescue-wheatgrass grasslands and sagebrush steppe. Riparian areas along small and most large streams were dominated primarily by willows. Drier terraces supported stands of basin big sagebrush. Basin wildrye was common on stream terraces and along the edges of riparian areas. Early records of vegetation for the study area are scanty at best. Nonetheless, the information compiled here suggests that a number of significant vegetational changes have occurred since European settlement. These changes can be attributed to three major causes: agriculture, fire suppression, and changes in grazing pressure.

\section{Agriculture}

Cultivation of hay crops has undoubtedly had a major impact on riparian and terrace vegetation. The primary habitat for basin wildrye and basin big sagebrush is stream terraces. Most of the stands of this vegetation reported by early explorers have now been replaced by hay meadows. Dewatering of streams for irrigation appears to be responsible for the loss of willows along streams in the Madison Valley and undoubtedly other areas as well. Impoundment and diversion are likely at least part of the cause for the recent decline of cottonwoods along the Beaverhead River above Dillon.

\section{Fire suppression}

Fire suppression has resulted in an increase in the density and extent of coniferous forests in southwest Montana (Arno and Gruell 1983, 1986, Gruell 1983). Young forests have expanded at the expense of grasslands and sagebrush steppe (Arno and Gruell 1986). Woodlands dominated by mountain mahogany and Rocky 
Mountain juniper have also increased in density, extent and age in the past 100 years (Gruell 1983), probably due to fire suppression (Gruell et al. 1985, Arno and Wilson 1986). On the other hand, it appears that many aspen forests have become decadent or have succumbed to encroachment by Douglas fir. These changes are also attributed, at least in part, to fire suppression (Gruell 1983, DeByle and Winokur 1985, DeByle et al. 1987).

Rangelands in southern Beaverhead County were a mosaic of grasslands and steppe (Vale 1975). The distribution of sagebrush was undoubtedly determined partly by soil relationships, but principally by the occurrence of fire. Average fire-return intervals at the ecotone between forest and sagebrush grasslands of the high valleys in southwest Montana were 25-50 years prior to European settlement (Arno and Gruell 1983, Houston 1973, Wright et al. 1979). Big sagebrush is easily killed by fire and often requires in excess of ten years to reestablish preburn stature and density (Blaisdell 1953, Mueggler and Blaisdell 1958, Harniss and Murray 1973). Although sagebrush was common prior to European settlement, areas dominated by sagebrush have increased, primarily as a result of fire suppression. Livestock grazing is sometimes implicated in the increase of sagebrush. However, sagebrush has increased at Big Hole Battlefield National Historic Site although it has been protected from livestock grazing for ca. 50 years (Pierce 1982).

\section{Grazing}

Bison were common in Beaverhead County before settlement, and the density of cactus and lack of grass reported by explorers and trappers suggests that grazing was severe in some areas. By the middle of the 19th Century, bison were exterminated, and domestic cattle replaced them as the primary grazers. In the latter part of the century livestock grazing was also severe up until the crash of the industry following the winter of 1887 (Phillips 1957). Nonetheless, we found no evidence that livestock grazing had any greater impacts on the upland vegetation than grazing by bison. Indeed, there may be more grass now than before European settlement or the end of open range (Dorn 1986).

Some of the changes in riparian or terrace vegetation in the past 100-150 years may be due to differences in grazing behavior between bison and cattle. Early 
descriptions of bison grazing in Beaverhead County suggest that they spent little time in riparian areas but grazed primarily in the uplands (Appendix A). On the other hand, domestic livestock, especially English breeds of cattle, spend a good deal of time grazing in riparian areas during summer. Declines in large grasses, such as basin wildrye, might be expected under strong grazing pressure (Weaver 1968). We suspect that much of the lower southwest part of the Centennial Valley supported extensive stands of basin wildrye that were replaced by smaller stature grasses and rabbitbrush during periods of severe overgrazing. Basin wildrye appears to be recovering in areas where grazing pressure is reduced or absent. Declines in some willows may also be partly attributed to livestock grazing (Clary et al. 1992, Schulz and Leininger 1990; Appendix C).

Cottonwood were apparently not common along the major rivers in southern Beaverhead County when Lewis and Clark visited the area in 1805, but beaver were abundant: "on all three rivers...are immense quantities of beaver, otter and muskrat" (Moulton and Dunlay 1988, p. 57). Thirty to fifty years later explorers and trappers reported abundant cottonwood forests along the Beaverhead River, and these forests persist today. It seems likely that the paucity of cottonwood early in the 19th Century was due to beaver. By the middle of the century beaver populations had been greatly reduced by trapping (Lewis and Phillips 1923), and cottonwoods were able to mature in many riparian areas. Extensive stands originating during the last 100-150 years are now declining. These declines may, in part, be a natural result of age. However, decline and an apparent lack of adequate recruitment along some reaches is probably a result of diversion and impoundment (Johnson et al. 1976).

Willows dominated riparian areas along smaller order streams. Beaver decrease willows by grazing, but they increase available willow habitat by raising the water table over substantial areas (Naiman et al. 1986, Neff 1957). The decline of beaver due to trapping in the late 19th Century may have caused a decline in willows in headwaters areas. Decline of willows in these areas is also likely due, in part, to irrigation (see above).

\section{ACKNOWLEDGMENTS}


We had helpful discussions and correspondence with Jim Christensen, Lou Hagener, Hank Greitl, Brian Hockett, Sue Linneman and Jim Roscoe. 


\section{LITERATURE CITED}

Arno, S. F. and A. E. Wilson. 1986. Dating past fires in curl-leaf mountain mahogany communities. Journal of Range Management 39(3): 242-243.

Arno, S. F. and G. E. Gruell. 1983. Fire history at the forest-grassland ecotone in southwestern Montana. Journal of Range Management 36(3): 332-336.

Arno, S. F. and G. E. Gruell. 1986. Douglas-fir encroachment into mountain grasslands in southwestern Montana. Journal of Range Management 39(3): 272-275.

Blaisdell, J. P. 1953. Ecological effects of planned burning of sagebrush-grass range on the Upper Snake River Plains. U.S. Department of Agriculture Technical Bulletin 1075, Washington D.C.

Bracket, A. G. 1917. A trip through the Rocky Mountains. Contributions to the Historical Society of Montana 8: 328-344.

Brower, J. V. 1897. The Missouri River and its utmost source. Pioneer Press, St. Paul, MN.

Burroughs, R. D. 1961. The natural history of the Lewis and Clark Expedition. Michigan State University Press, East Lansing.

Clary, W. P., E. D. McArthur, D. Bedunah and C. L. Wambolt (eds.). 1992. Symposium on ecology and management of riparian shrub communities. U. S. Forest Service General Technical Report INT-289.

Cooper, S.V., P. Lesica, R. L. DeVelice, T. McGarvey. 1995. Classification of southwestern Montana plant communities with emphasis on those in the Dillon Resource Area, Bureau of Land Management. Montana Natural Heritage Program, Helena. $152 \mathrm{p}$. 
DeByle, N. V., C. D. Bevins and W. C. Fischer. 1987. Wildfire occurrence in aspen in the interior western United States. Western Journal of Applied Forestry 2: 73-76.

DeByle, N. V. and R. P. Winokur (eds.). 1985. Aspen: ecology and management in the western United States. U.S. Forest Service General Technical Report RM-119, Fort Collins, CO. $283 \mathrm{p}$.

Dorn, R. D. 1986. The Wyoming landscape, 1805-1878. Mountain West Publishing, Cheyenne, WY.

Gilkerson, M. 1980. Historical comparison photography. Mountain foothills, Dillon Resource Area. USDI Bureau of Land Management, Billings, MT.

Gruell, G. E. 1983. Fire and vegetative trends in the Northern Rockies: interpretations from 1871-1982 photographs. USDA Forest Service General Technical Report INT 158, Ogden, UT.

Gruell, G. E., S. Bunting and L. Neuenschwander. 1985. Influence of fire on curl-leaf mountain mahogany in the Intermountain West. Pages 58-72 in J. K. Brown and J. Lotan (eds.), Fire's effects on wildlife habitat. U. S. Forest Service General Technical Report INT-186.

Haines, A. L. (ed.). 1955. Osborne Russell's journal of a trapper. Oregon Historical Society and Champoeg Press, Portland.

Harniss, R. O. and R. B. Murray. 1973. 30 years of vegetal change following burning of sagebrush-grass range. Journal of Range Management 26(5): 322-325.

Hayden, F. V. 1869. Geological report of the exploration of the Yellowstone and Missouri rivers, 1859-60. U.S. Government Printing Office, Washington DC. 
Hayden, F. V. 1872. Preliminary report of the United States Geological survey of Montana and adjacent territories. Fifth annual report of progress. U.S. Government Office, Washington DC.

Hayden, F. V. 1873. Sixth annual report of the United States Geological Survey embracing portions of Montana, Idaho, Wyoming and Utah; being a report of progress of the explorations of the year 1872. U.S. Government Office, Washington DC.

Houston, D. B. 1973. Wildfires in northern Yellowstone National Park. Ecology 54: 1111-1117.

Johnson, W. C., R. L. Burgess, and W. R. Keammerer. 1976. Forest overstory vegetation and environment on the Missouri River floodplain in North Dakota.

Ecological Monographs 46(1): 59-84.

Knowles, C. J. and P. R. Knowles. 1993. A bibliography of literature and papers pertaining to presettlement wildlife and habitat of Montana and adjacent areas. USDA Forest Service, Region One, Missoula, MT.

Lewis, W. S. and P. C. Phillips (eds.). 1923. The journal of John Work. Arthur H. Clark Co., Cleveland, $\mathrm{OH}$.

Moulton, G. E. (ed.). 1993. The journals of the Lewis and Clark Expedition. Volume 8. University of Nebraska Press, Lincoln.

Moulton, G. E. and T. W. Dunlay (eds.). 1988. The journals of the Lewis and Clark Expedition. Volume 5. University of Nebraska Press, Lincoln.

Mueggler, W. F. and J. P. Blaisdell. 1958. Effects on associated species of burning, rotobeating, spraying and railing sagebrush. Journal of Range Management 11: 61-66. 
Mullan, J. 1855. Report of a reconnaissance from the Bitter Root valley to Fort Hall and back. In. I.I. Stevens (compiler), Report of exploration of a route for the Pacific Railroad- Governor Steven's report to the Secretary of War. Senate Executive Document 78, 33rd Congress, 2nd Session, Vol. 1, Washington DC.

Naiman, R. J., J. M. Mellilo, and J. E. Hobbie. 1986. Ecosystem alteration of boreal forest streams by beaver (Castor canadensis). Ecology 67: 1254-1269.

Neff, D. J. 1957. Ecological effects of beaver habitat abandonment in the Colorado Rockies. Journal of Wildlife Management 21: 80-84.

Phillips, P. C. (ed.) 1940. Life in the Rocky Mountains by W. A. Ferris. The Old West Publishing Company, Denver, CO.

Phillips, P. C. (ed.). 1957. Forty years on the frontier as seen in the journal and reminiscences of Granville Stuart. The Arthur Clark Co., Glendale, CA.

Pierce, J. R. 1982. A floristic study of the Big Hole National Battlefield. M.A. thesis, University of Montana, Missoula.

Raynolds, W. F. 1868. Report on the exploration of the Yellowstone and Missouri rivers in 1859-1860. Senate Executive Document 77, 40th Congress, 2nd Session. No. 1317. Government Printing Office, Washington DC.

Scarborough, V. 1974. Archeological and historical survey in the west Dillon and Tendoy mountain planning units of Beaverhead County, southwestern Montana. Western Interstate Commission for Higher Education, Boulder, CO.

Schulz, T. T. and W. C. Leininger. 1990. Differences in riparian vegetation structures between grazed areas and exclosures. Journal of Range Management 43: 295-299. 
Stibal, D. 1990. Centennial Valley. Pages 44-46 in The History of Beaverhead County. Beaverhead County History Book Association, Dillon, MT.

Vale, T. R. 1975. Presettlement vegetation in the sagebrush-grass area of the Intermountain West. Journal of Range Management 28: 32-36.

Weaver, J. E. 1968. Prairie plants and their environment. University of Nebraska Press, Lincoln.

Wright, H. A., L. F. Neuenschwander and C. M. Britton. 1979. The role and use of fire in sagebrush grass and pinyon-juniper plant communities. USDA Forest Service General Technical Report INT-58. Ogden, UT. 
Appendix A. Observations of bison made by early trappers in Beaverhead and adjacent Madison counties. Only references that mention habitat are included.

W. A. Ferris in fall and winter of 1931 (Phillips 1940)

near Whitehall: "we found the plains alive with buffalo" (p.113)

Ruby River: "...Indians came into the plain in pursuit of a herd of buffalo..." (p.118)

Ruby Reservoir: ...descended into an open valley which we found covered with buffalo" (p.118)

Big Hole: "We found the herd grazing in a narrow bottom" (p.165)

Twin Bridges: "...we saw several fine herds of buffalo, and our hunters reported that the plains were covered with them near Beaver Head" (p.171)

Madison Valley: "...we discovered a herd of buffalo, lying in a ravine sheltered from the storm..." (p.173)

Ruby Valley: "...perceived traces of Indians following a buffalo trail up along the margin of the river. The neighboring hills were covered with vast herds of these animals..." (p.176)

Dillon: "...encamped on a very narrow level at its [Beaverhead River's] margin...some few elk and antelopes are found here and buffalo in abundance" (p.181)

John Work in fall and winter of 1931 (Lewis and Phillips 1923)

Big Hole: "Some herds of bulls were seen feeding on the hills..." (p.101)

Big Hole: "From a hill numbers of buffalo were seen in the plain ahead of us." (p.101) 
Dillon: "...we encamped a little above the Beaverhead, here the plains on both sides of the river are covered with large herds of buffalo..." (p.105)

Horse Prairie: "...they saw some buffalo towards the mountains..." (p.122)

Dillon: "There are buffalo along the mountains on both sides of the river but at a considerable distance." (p.124)

Apex: "Some buffalo in the mountains but none near." (p.126)

Apex: "A herd of buffalo were driven down from the hills..." (p.126)

Dillon: "Some herds of buffalo were seen along the mountains..." (p.130)

Dillon: "...there were several herds yesterday along the mountains." (p.130)

Horse Prairie: "The buffalo were on their way descending the river." (p.131)

Horse Prairie: "There are considerable numbers in the hills hard bye..." (p.132)

Horse Prairie: "Large herds of buffalo were seen coming over the hills towards evening..." (p.133)

Horse Prairie: "A herd of buffalo were observed descending the mountains." (p.135) Osborne Russell in September, 1835 (Haines 1955)

Ruby River: "...large numbers of buffaloe were scattered over the plains and among the hills" (p.33) 
Appendix B. Comparison of vegetation dominated by Elymus cinereus or Artemisia tridentata ssp. tridentata inside and outside livestock exclosures in southern Beaverhead County.

Introduction

Grazing by large ungulates, including domestic livestock may have a profound impact on grassland and steppe vegetation. The effect of grazing on the composition of plant communities can be explored experimentally using livestock exclosures or fence lines that separate two contrasting grazing regimes. Comparison of vegetation inside and immediately outside exclosures provides information on how different plant species respond to grazing. This knowledge can be used to help understand how vegetation changed following the introduction of livestock grazing. However, cautious interpretation is necessary because grazing by native ungulates was an integral part of grasslandsteppe ecosystems in southwest Montana. Grazing by domestic livestock may or may not have effects similar to grazing by bison.

Vegetation dominated by either Elymus cinereus or Artemisia tridentata ssp. tridentata is of limited extent in Montana and has been little studied (Mueggler, W. F. and W. L. Stewart. 1980. Grassland and shrubland habitat types of western Montana. USDA Forest Service General Technical Report INT-66, Ogden, UT.). The purpose of our study is to describe this vegetation inside livestock exclosures and compare it to adjacent plant communities subject to grazing.

\section{Methods}

\section{Study sites}

All study sites are in southern Beaverhead County except Kaufman Guard Station which is in adjacent Lemhi County, Idaho.

\section{Elymus cinereus sites}

(1) Indian Creek. T14S R12W S34 NE1/4. 7,750 ft. A livestock exclosure was established in ca. 1981 
(2) Red Rock Lakes \#1 West. T14S R2W S6 SE1/4. 6,610 ft. Fenceline grazing contrast established in 1936; for at least previous 20 years west side grazed annually; east side (exclosure) grazed one year in every three or four.

(3) Red Rock Lakes \#2 West. T14S R2W S16 SW1/4, S17 SE1/4. 6,600 ft. Fenceline grazing contrast established in 1936; for at least previous 20 years west side grazed annually; east side (exclosure) grazed one year in every thee or four.

(4) Kaufman Guard Station. T11N R29E S35 SW1/4. 6,400 ft. A livestock exclosure was established in ca. 1955. Occasional grazing by horses has occurred.

Artemisia tridentata ssp. tridentata site

(1) Shenon Creek. T10S R13W S32 NW1/4. 6,640 ft. Livestock exclosure established in ca. 1981.

\section{Field Methods}

At each site we established two temporary, circular 1/10-acre plots in representative locations: one inside and one immediately outside the exclosure. Within each plot we estimated the canopy cover of all vascular plant species to the nearest $10 \%$ on Montana Natural Heritage Community Survey forms. Kaufman Guard Station and Big Spring Gulch were sampled in late June 1995; all other sites were sampled in late August 1996.

Results and Discussion

\section{Elymus cinereus communities}

The presence of Artemisia tridentata ssp. vaseyana at one site and Sarcobatus vermiculatus at another indicate that the sites sampled may not be the same habitat types (i.e., will not support the same potential natural vegetation). Nevertheless, three trends are apparent in the data (Table B-1): sample plots in exclosures had (1) higher cover of Elymus cinereus, (2) higher cover of Poa juncifolia, and (3) lower cover of broad-leaved forbs.

These results suggest that livestock grazing is capable of greatly reducing the abundance of $E$. cinereus on sites where it would otherwise dominate. Tall, erect stature and caespitose growth form make $E$. cinereus sensitive to grazing by large 
herbivores because most of its vegetative biomass is situated well above ground level. The coarse late-season vegetation and abundance of dead stems and leaf litter will sometimes deter livestock from grazing $E$. cinereus. However, livestock grazing pressure is often intense in valley-bottom sites where $E$. cinereus has the potential to dominate, and under these circumstances we believe it will decline rapidly. With heavier grazing pressure E. cinereus was replaced by broad-leaved forbs such as Antennaria microphylla, Haplopappus uniflorus and Phlox kelseyi or short-stature grasses such as Distichlis stricta, Festuca idahoensis and Puccinellia nuttalliana.

\section{Artemisia tridentata ssp tridentata community}

Agropyron smithii, Elymus cinereus, and Poa juncifolia increased in the absence of grazing, although the changes in the latter two species were not large. The cover of basin big sagebrush, Carex praegracilis and the exotic Poa pratensis were higher in the grazed area. The increase in cover of Elymus cinereus is consistent with results from the $E$. cinereus communities (above). The fact that the difference was small after 15 years suggests that recovery of $E$. cinereus is slow in these sites. However, these conclusions are based on a single site and should be viewed with skepticism. 
Table B-1. Canopy cover of common vascular plants in grazing exclosure (Exc) and outside exclosure (Grz) plots at four sites: Indian Creek, Red Rock Lakes \#1, Red Rock Lakes \#2, and Kaufman Guard Station.

Elymus cinereus communities

Artemisia tridentata ssp.vaseyana

Chrysothamnus nauseosus

Sarcobatus vermiculatus

Agropyron smithii

Carex praegracilis

Distichlis stricta

Elymus cinereus

Festuca idahoensis

Juncus balticus

Koeleria cristata

Poa juncifolia

Poa pratensis

Puccinellia nuttalliana

Achillea millefolium

Antennaria microphylla

Haplopappus uniflorus

ris missouriensis

Phlox kelseyi

Potentilla gracilis

Artemisia tridentata ssp. tridentata communities

Artemisia tridentata ssp. tridentata

Chrysothamnus nauseosus

Ribes setosum

Agropyron smithii

Carex praegracilis

Elymus cinereus

Poa juncifolia

Poa pratensis

Achillea millefolium

Antennaria microphylla

Aster occidentalis

Iris missouriensis

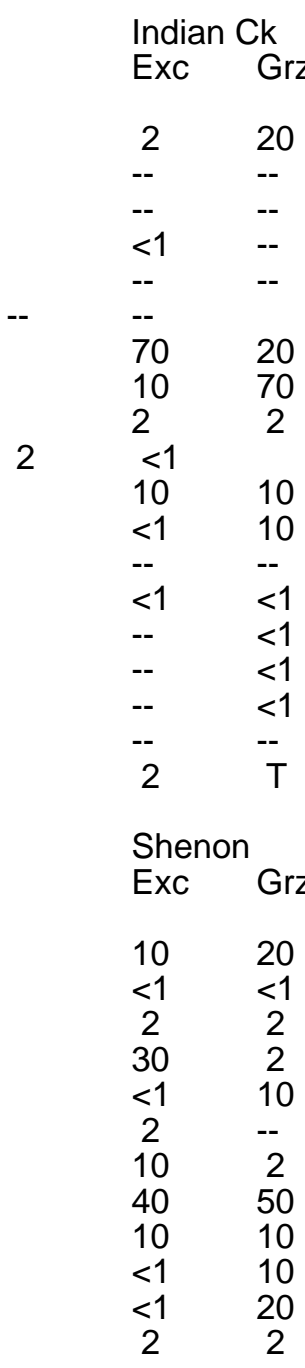

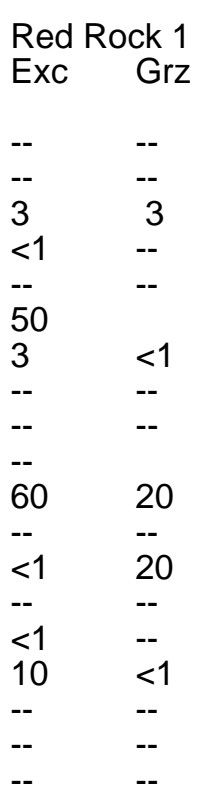

Red Rock 2

Exc Grz

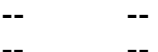

$--1$

$10 \quad 20$

$30 \quad 2$

$<1$

--

$<1$

20

20

2

$<1$

2

$<1$

$-$
2
Kaufman

Exc Grz

2

$--$

$2 \quad 10$

60

2

$<1 \quad 2$

$\begin{array}{cc}2 & -- \\ -- & -- \\ -- & -- \\ -- & -- \\ -- & 10 \\ -- & 2 \\ -- & -- \\ -- & 30 \\ -- & 2\end{array}$


Appendix C. Number of willow plants along stream banks inside and outside of livestock exclosures on three stream reaches in southern Beaverhead County.

\section{Introduction}

Grazing by large ungulates, including domestic livestock may have a profound impact on riparian vegetation. The effect of grazing on the composition of plant communities can be explored experimentally using exclosures or fence lines that separate two contrasting grazing regimes. Comparison of vegetation inside and immediately outside exclosures provides information on how different plant species respond to grazing. This knowledge can be used to help understand how vegetation changed following the introduction of livestock grazing. However, cautious interpretation is necessary because grazing by native ungulates was an integral part of grasslandsteppe ecosystems in southwest Montana. Grazing by domestic livestock may or may not have effects similar to grazing by bison.

Willow communities commonly occur along streams in southern Beaverhead County. Many researchers believe that the density of willows often decrease under livestock grazing pressure (Hansen, P., R. Pfister, K. Boggs, B. J. Cook, J. Joy, and D. K. Hinkley. 1995. Classification and management of Montana's riparian and wetland sites. University of Montana School of Forestry, Missoula, MT). The purpose of our study is to test this hypothesis by comparing the number of willows inside and outside three livestock exclosures along two streams.

Methods

\section{Study sites}

Shenon Creek is a tributary of Horse Prairie Creek southwest of Clark Canyon Reservoir. Muddy Creek is a tributary of Big Sheep Creek west of Lima. (1) Shenon Creek. T10S R13W S32 NW1/4. 6,640 ft. Livestock exclosure established in ca. 1981.

(2) Muddy Creek South. T13S R10W S33 NW1/4, 6,670 ft. Riparian exclosure established in ca. 1967.

(3) Muddy Creek North. T13S R10W S20 SW1/4, ca. 6,760 ft. Riparian exclosure established in ca. 1967. 


\section{Field Methods}

We sampled riparian communities by counting the number of willow plants (i.e., discrete clusters of stems) by species along and on both sides of the stream for a predetermined distance both inside and immediately outside each exclosure:

Shenon Creek- $500 \mathrm{ft}$

Muddy Creek South- $950 \mathrm{ft}$

Muddy Creek North- $700 \mathrm{ft}$.

Distances were chosen to sample most of the stream reach within the exclosure at each site. At Shenon Creek willow plants with stems greater than 1 inch at the base were not counted because they were almost certainly present before the exclosure was constructed. Large willows were not present at the Muddy Creek sites. Sampling was conducted in late August 1996.

\section{Results and Discussion}

There were 217\%, 360\% and 56\% more willow plants inside livestock exclosures compared to outside at Shenon Creek, Muddy Creek South and Muddy Creek North respectively (Table C-1). With one exception, all species of willows were more abundant inside exclosures at all sites (Table C-1). At Shenon Creek there was 460\% more Salix bebbiana but only $155 \%$ more other willows inside the exclosure, a significantly greater difference for $S$. bebbiana $\left(\chi^{2}=3.87, P=0.05\right)$. There were no other differences in responses among willow species to cessation of grazing at any of the sites $(P>0.36)$.

Results of this study indicate that livestock grazing does result in a reduction of willows along small streams, assuming that the density of willows inside and immediately outside the exclosures were equal at the time they were constructed. In addition to an overall decline in Salix species, grazing apparently caused a disproportionate reduction of S. bebbiana compared to S. boothii and S. geyeriana at Shenon Creek. This suggests that $S$. bebbiana may be more sensitive to grazing than the other two species.

Table C-1. Number of willow plants inside (Exc) and outside (Grz) grazing exclosures at three sites in southern Beaverhead County. 


\begin{tabular}{|c|c|c|c|c|c|c|}
\hline & \multicolumn{2}{|c|}{ Shenon } & \multicolumn{2}{|l|}{ Muddy South } & \multicolumn{2}{|c|}{ Muddy North } \\
\hline & Exc & Grz & Exc & Grz & Exc & Grz \\
\hline Salix bebbiana & 51 & 9 & -- & -- & -- & -- \\
\hline Salix boothii & 62 & 24 & 16 & 2 & 4 & 2 \\
\hline Salix exigua & -- & -- & 21 & 8 & -- & -- \\
\hline Salix geyeriana & 30 & 12 & 2 & 0 & 21 & 13 \\
\hline Salix lutea & -- & -- & 1 & 0 & -- & -- \\
\hline Salix pseudomonticola & -- & -- & 6 & 0 & 0 & 1 \\
\hline
\end{tabular}

